\title{
The Post Priok TRIals: RELIGIOUS PRINCIPLES AND LEGAL ISSUES
}

\author{
Peter Burns*
}

\section{Introduction}

In January 1985 the government of the Republic of Indonesia initiated a series of prosecutions. Commonly identified as the subversion trials, these shared the following characteristics:

the defendants were Muslims, 1

the offenses with which the defendants were charged fall under the heading of political crimes, ${ }^{2}$

the cases were linked with what happened in Tanjung Priok in the first half of September 1984.

The second part of this article will offer analyses and interpretations of the various beliefs and motives of the men who clashed physically, at Tanjung Priok, or ideologically, in the subsequent legal battles. That speculative exercise will require, however, an initial statement about what happened.

\footnotetext{
*In preparing this article, I received information and assistance from legal aid lawyers from various parts of Indonesia. For their protection I shall not thank them here by name. I am also grateful to officers of the Amnesty International Secretariat in London for access to a collection of documents relating to the Tanjung Priok cases. I am particularly indebted to Ms. Carmel Budiardjo, of the Tapol organization in London, for allowing me free use of the extensive file of press reports held in the Tapol office. These enabled me to resolve many factual questions concerning the subversion trials. Dr. John MacDougall, of Indonesia Publications, Maryland, provided material on the events at Tanjung Priok. He read a draft of this article. I am most grateful for his comments and advice.

${ }^{1}$ The exception is Ferdinand Silahi, and he chose to become a Muslim in jail. Tapol, Indonesia: Muslims on Trial (London: The Indonesian Human Rights Campaign, 1987), p. 30.

${ }^{2}$ Note that General Ali Said, then chairman of the Indonesian Supreme Court, denied that the system of justice in Indonesia takes cognizance of such a category. See the Jakarta Post, July 25, 1985, p. 3.
} 


\section{Preliminary Information}

\section{The Events at Tanjung Priok}

On Friday September 7, 1984,3 Staff-Sergeant Hermanu, a neighborhood security officer (Babinsa) of the subdistrict military command (Koramil), visited the Assacadah prayer-house (mushollah) at Gang (Alley) 4, Koja Selatan, an area in Tanjung Priok, the dockland suburb on the north side of Jakarta. He was accompanied by a fellow security officer (Wanra Koramil) named Sukram. Hermanu directed that certain posters be removed. One of the eight young men in the prayer-house obeyed this instruction. When Hermanu returned the next day, accompanied by another security officer named Samin, he again discovered notices fixed to the wall of the prayer-house. One of the officers reportedly entered the building without removing his footwear, and one used drain water in an attempt to make the wall-posters illegible. Local Muslims felt that their place of worship had been wantonly desecrated. Having heard about this trouble, Achmad Sahi, the chairman of the mushollah, complained to the head of the neighborhood citizens' association, who asked him to verify his information and told him to write a report. 4

On Monday September 10, a part-time voluntary community worker, Syarifuddin Rambe, and his associate, Sofwan Sulaeman, both from the administration of the Baitul Makmur mosque in Koja, encountered Hermanu while he was on duty with another security officer, Sergeant-Major Edy Surachmat. As an initiative towards the reduction of cormmunity tension, they invited Hermanu to the office of the neighborhood citizens' association (pos $R w .05$ gang $V$ ). They proposed that Hermanu should apologize for what had happened on September 8. Hermanu went along with the first request but proved quite unwilling to concede any fault in his behavior. A crowd gathered outside the office. Surachmat, who was waiting for Hermanu, was struck, and took refuge in the office. Sofwan Sulaeman helped Surachmat to stop the attackers from breaking in. Hermanu's motor-cycle was set on fire. Reinforcements from the subdistrict command brought this confrontation to an end. Muhammad Noor, an unemployed youth, was detained and charged for, inter alia, his part in the destruction of the motor cycle. Then Syarifuddin

\footnotetext{
${ }^{3}$ The "White Paper on the September 1984 Incident in Tanjung Priok" (reproduced in English translation in Tapol, Muslims on Trial, pp. 107-11 as Appendix IV, from the original document, Lembaran Putih (twenty-two signatories, Jakarta, September 17, 1984) does not mention September 7. Nor does Amnesty International, Indonesia: Muslim Prisoners of Conscience (London: Amnesty International Publications, 1986). Muslims on Trial, p. 19, indicates, however, that Hermanu did visit the prayer-house on that date. This is confirmed by the first three of the following sources: Jakarta Post (January 14, 1985), Sinar Harapan (January 11, 1985) and Team Pembela Kasus Mubaligh/Pidana Politik, Pembelean Kasus Priok (Jakarta: Lembaga Bantuan Hukum, 1985?) pp. 11, 55, 57. "Rabu Malam Berdarah di Tanjung Priok" (a pamphlet apparently originating from alAraf Mosque in Tanjung Priok, translated in Indonesia Reports [College Park, Md.] Politics Supplement, January 15, 1985, p. 1, says there were three officers. There is no suggestion that the security officers failed to remove their footwear before entering the prayer-house on September 7.

${ }^{4}$ Panji Masyarakat, no. 444, September 21, 1984 carried a report of the official government statement issued by General Benny Murdani, which claimed (p. 47) that pamphlets and posters displayed around the Rawa Bada mosque had been blacked out by a security official on September 7. It claimed that repeated warnings had been ignored. The content of the posters was inflammatory-SARA-it claimed. (SARA is an acronym touching on suku [tribal], agama [religious], ras [racial], and antar-golongan [inter-communal] issues). For differing versions of the content of the posters and the method of their removal, see Jakarta Post, January 4, 9 , 11, 14, 18, and 21, 1985; Tempo, January 19, 1985; Sinar Harapan, December 22, 1984, January 11, 1985; Tapol, Muslims on Trial, pp. 19, 23, 107; Panji Masyarakat, September 21, 1984, p. 46; and Team Pembela, Pembelaan Kasus Priok, pp. 12, 47, 55, 57, 58.
} 
Rambe and Sofwan Sulaeman were arrested. Learning of this new disturbance, Achmad Sahi came to the office, and was taken into custody on his arrival. 5

The following day, Tuesday September 11, Amir Biki, a businessman, tried to negotiate with the authorities. He had a good relationship with a high-ranking military officer-a deputy governor in the Jakarta municipal administration-and had previously had some success in resolving conflicts. ${ }^{6}$ On this occasion, however, his endeavor was in vain.

On the morning of September 12, a regular preacher (mubalig), Abdul Qadir Djaelani, drafted a petition, entitled Ikrar Umat Islam Jakarta ${ }^{7}$ (cited hereafter as the Jakarta Confession), which asked the government to abandon legislative plans to oblige every formal association in Indonesia-including the religious organizations-to adopt a uniform ideology. The petition had been drawn up in Tanjung Priok and was endorsed by other preachers, some of whom were to speak at the religious meeting scheduled for that evening. One of the signatories, Ratono, went round Tanjung Priok canvassing support for the rally. 8

During the evening, while the mubalig were speaking, Amir Biki tried again to secure the freedom of the detainees. ${ }^{9}$ Eventually, he issued an ultimatum, setting eleven o'clock that night as the deadline for the release of the four men. There are conflicting reports as to whether Amir Biki threatened the authorities with violence, or counselled the demonstrators to act with self-restraint in their protest. ${ }^{10}$ When the time he had set expired, the mass meeting became a mass march. According to "Rabu Malam Berdarah," three columns formed, each with a different destination. This may have reflected uncertainty among the protesters about where the prisoners had been taken. The marchers moved onto the Jakarta By-Pass Road and one column had almost reached its goal-the police station-when they were faced with government troops. The troops shot at them. Amir Biki was killed. According to the government account, no more than eight others died: a threatening crowd, "many members of which were armed with homemade

\footnotetext{
${ }^{5}$ For varying accounts of these incidents, see Sinar Harapan, January 11, 1985; Jakarta Post, January 4, 8, 11, 14, 15, 1985; Tapol, Muslims on Trial, pp. 19, 23 et passim; Amnesty, Prisoners of Conscience, pp. 2, 8, 21, 22; Team Pembela, Pembelaan Kasus Priok, p. 56ff., 62, 64.

${ }^{6}$ On Amir Biki's role, see Amnesty, Prisoners of Conscience, p. 8, 31; Tapol, Muslims on Trial, p. 108; Indonesia Reports, January 15, 1985, p. 5; Panji Masyarakat, September 21, 1984, p. 48; Jawa Pos, September 14, 1984; Tempo, January 19, 1985, p. 13.

7 Literally: Confession of Faith by the Islamic Community of Jakarta.

${ }^{8}$ Tapol, Muslims on Trial, p. 56ff., discusses the petition and gives the names of thirteen signatories: among those who took part in the meeting were Amir Biki, Ratona, Salim Qadir, Yayan Hendrayana, Syarifin Maloko, and Mohamad Nasir. Nasir, a particularly provocative speaker, has not been seen since that night.

${ }^{9}$ He made several phone calls (John MacDougall, p.c.) to the Kodim (Military District Commands) of North Jakarta. "Rabu Malam Berdarah" (in Indonesia Reports-Politics Supplement, January 15, 1985, p. 5) cites an eye witness report that he communicated with Kodim by letter.

${ }^{10} \mathrm{He}$ threatened slaughter (pembunuhan), according to Panji Masyarakat, September 21, 1984, p. 47; a bloodbath (banjir darah), Tempo, January 19, 1985, p. 16, quoting Tempo, September 22, 1984. See also Amnesty, Prisoners of Conscience, p. 9. For the conflicting reports, see Team Pembela, Pembelaan Kasus Priok, p. 14; Tapol, Muslims on Trial, p. 108. See also "Rabu Malam Berdarah," which presents him as opposed to precipitate action.
} 
weapons," had forced the soldiers to fire in self-defense, it said. ${ }^{11}$ Unofficial reports challenged the truth of the official explanation and put the death-count much higher. ${ }^{12}$

\section{Arrests}

Four men were already in custody. Though the authorities apparently required some weeks to formulate and publish clear charges against them, their arrests had provided the immediate motive for the midnight march on September 12. As a direct consequence of that demonstration, many more Muslims were detained, "about two hundred ... at Cimanggis army detention centre." 13 Twenty-eight of them-mostly young men-were to be brought before the courts. Each was alleged to have taken part in the march and each was charged with violent resistance to constituted authority. Twenty had been wounded. ${ }^{14}$

Two preachers from the rally were also to be arrested, and charged with incitement to riot. ${ }^{15}$ By the end of the week, at least five other Islamic preachers had been taken into custody, four of whom had signed the Jakarta Confession. ${ }^{16}$ They were charged with subversion. It was to be argued that, though they had not been at Tanjung Priok, the substance of their earlier sermons constituted indirect incitement to rebellion. And again, thereafter, the authorities were to detain more Islamic leaders-outspoken critics of the government establishment and its policies. The charges in most cases remained much the same: sedition and the spreading of disaffection. This practice was to continue through 1985. Other later detainees have proved to be Islamic enthusiasts enrolled for intensive upgrading studies of their religion, or members of usroh groups-informal domestic devotional gatherings for raising Islamic consciousness. ${ }^{17}$

Subversion formed the basis of charges against some of those arrested for possession, reproduction, or distribution of pamphlets or cassettes which questioned the official explanation of events at Tanjung Priok. Those detained in Jakarta, where leaflets offer-

\footnotetext{
${ }^{11}$ See the official version, as reported in Amnesty International, The Tanjung Priok Incident (London: Amnesty pamphlet, June 1986). Conflicting evidence about violent intentions and action was presented in court during the trial of twenty-eight men accused in connection with the Tanjung Priok march. Panji Masyarakat, September 21,1984, contains photographs and a report of property destroyed in the suburb. Jawa Pos, September 15, 1984, tells of harm done to the homes and cars of Chinese citizens resident in Tanjung Priok.

${ }^{12}$ The unofficial reports include "Rabu Malam Berdarah" and Lembaran Putih (White Paper) cited through the above notes and the various printed leaflets and cassette tape recordings which soon became the target of government prosecutions. Team Pembela, Pembelaan Kasus Priok, p. 27, cites an article in the Far Eastern Economic Review, reporting that hundreds of people had been killed.

${ }^{13}$ According to a fellow prisoner (Haji A. M. Fatwa)-See Tapol, Muslims on Trial, p. 25.

${ }^{14}$ Tapol, Muslims on Trial, pp. 26-31, amends the spelling in six places in the list of names provided in Amnesty, Prisoners of Conscience, p. 9 ff.

${ }^{15}$ Yayan Hendrana and Salim Qadar. The rally organizer, Ratono, was detaincd at the same time. Much later the preacher, Syarifin Maloko, was discovered and arrested far from Jakarta.

${ }^{16}$ Oesman al-Hamidy, Mawardi Noor, Tony Ardic, and Djaclani, the man who had drawn up the petition.

${ }^{17}$ Later detainees included Haji Fatwa, Abdul Laticf bin Amir, Drs. Hasan Kiat, and Muchamad Usman. See Amnesty, Prisoners of Conscience, pp 27-30, 35-37; Tapol, Muslims on Trial, pp. 62-64; $67 \mathrm{ff}$. Three young detainees (Murjoko, Faizal Fachry, and Andi Sukisno) from Malang in East Java were participants in an Islamic crash course. See Tapol, Muslims on Trial, pp. 69-71.
} 
ing an alternative version had appeared in mid-September, were charged, however, under the criminal code. ${ }^{18}$

The criminal code should have supplied the basis for charges arising from the subsequent bombing of buildings in Jakarta, branches of the BCA (Bank Central Asia) and a shopping complex where, on October 11, two people died. One would have expected a charge of murder or manslaughter. Yet, the offence was cited as subversion. Twelve people were charged but only eleven were arrested: one of the accused, Abdul Qadir Djaelani, had been in custody since September 13. This Jakarta bombing marked the beginning of a series of explosions which seemed prima facie to express frustrated aggression in reaction to the deaths at Tanjung Priok. On Christmas Eve, two Christian buildings (one Catholic, one Protestant) were damaged by explosions in Malang, East Java. Two young men were arrested, putatively as culprits in the bombing. One month later, in the New Year, the pattern was repeated: two more Malang men were arrested. This time, however, the bombing occurred in Central Java, wrecking the sculpture and masonry of nine stupas at the top of the newly restored great Buddhist temple at Borobudur. Nobody was killed in Malang or in Central Java. Seven people were to die, however, in a premature explosion on a night express bus in East Java. Three of the victims, it seems, were members of the terrorist group. Seven arrests followed. No criminal charges arose, however, from the wave of mysterious fires which broke out in different parts of Indonesia at the same time as the bomb outrages, during the ten months following the September confrontation. ${ }^{19}$

The most prominent figure charged in connection with the Jakarta bombings was Ir. Haji Sanusi. Sanusi had been an early supporter of the present Indonesian establishment, the New Order of President Suharto. A government minister (for Light Industries) from 1966-1968, he had associated in more recent years with a non-parliamentary opposition group known as Petisi 50. Petisi 50 was not a formal organization: it functioned as a label identifying persons who had signed a criticism submitted to the government in 1980. Some of the petitioners continued to meet on occasions. Two of them-retired Lieutenant-General Hartono Rekso Dharsono (another former establishment figure) and Haji Andi Mappetahang Fatwa-were also charged with subversion. ${ }^{20}$ They had endorsed-along with Sanusi and nineteen others-the Lembaran Putih (White Paper), the document which had questioned the government version of events: they had called for an independent enquiry into the whole Tanjung Priok affair. Both men were to protest later, in the course of their trials, that the manner of their arrest was irregular, contrary to the provisions of the newly enacted law of criminal pro-

\footnotetext{
${ }^{18}$ Government prosecutions were based on the substance of the pamphlets, rather than the fact of their existence: pamphleteers were charged with violation of the Criminal Code, Articles 64 and 65, to wit: "spreading false information that might lead to public unrest" (Amnesty, Prisoners of Conscience, p. 39ff.). Reproduction, distribution or, even, possession of a pamphlet constituted sufficient grounds for a criminal charge. See also ibid., pp. 37-42.

${ }^{19}$ See Tapol, Muslims on Trial, p. $71 \mathrm{ff}$.

${ }^{20}$ Lieutenant-General Dharsono had served as Ambassador for Indonesia in Thailand and Cambodia, and as Secretary-General of ASEAN. For a general description, see Robert Cribb, "The Trials of General Dharsono," in Inside Indonesia (Northcote, Melbourne) No. 7, May 1986 or Amnesty, Prisoners of Conscience, p. 23ff. On Haji Fatwa, see Tapol, Muslims on Trial, p. 62ff., Amnesty, Prisoners of Conscience, p. 27ff.
} 
cedure (KUHAP). ${ }^{21}$ Sanusi was to face a second trial on the charge of plotting to kill the Head of State.

In the years after 1984, more than one hundred persons faced charges directly or indirectly related to the events at Tanjung Priok. I make no attempt in the following notes to do justice to each of those cases nor to present an overall survey using representative samples of the various types of trials. ${ }^{22}$ I see my task, rather, to select sections from the proceedings-just enough to show what gave rise to those accusations. That is, I have to show the prima facie case which, it is claimed, the Indonesian establishment ought to answer.

\section{Trials}

The trial of Achmad Sahi, accused of having inflamed public opinion by deliberate dissemination of false information, was linked in tandem with that of Syarifuddin Rambe and Sofwan Sulaeman, the two mosque officials who had met Sergeant Hermanu on September $10 .{ }^{23}$ Sahi denied having told the two men about the reported sacrilege: his previous admission to that effect was given, he said, only when he could no longer bear the beating. ${ }^{24}$ The defense lawyers for these tandem trials planned to present eyewitness evidence about the violation of the prayer-house. Over extraordinary objections from the prosecution, they did succeed in introducing an elderly carpenter, Saleh, seeking as they did so that the bench should give him its protection. The trial judges could not, or would not, guarantee his safety, stating only that he would be free from interference within the court building. After some dispute over his competence to testify, Saleh was dismissed. He was intercepted on his way home and taken to the police station for lengthy questioning. Other potential witnesses at once withdrew their offers to testify. The defense lawyers asked the court to view the site in Tanjung Priok. They would show, they claimed, that prosecution witnesses could not have seen what they claimed to have seen. Initially the judges agreed. Later, the approval was revoked; security officials had declared that the area was still unsafe. Though it emerged that Sahi's information was substantially correct, and that Rambe and Sulaeman had used no violence, each was found guilty and sent to jail for thirty months. ${ }^{25}$

\footnotetext{
${ }^{21}$ A short survey of both the previous legal situation and the formation of the KUHAP is given in Keputusan Menteri Kehakiman Republik Indonesia Nomor: M.01.pw.07.03 th. 1982 tentang Pedoman Pelaksanaan Kitab Undang-undang Hukum Acara Pidana Bab I-II. See Abdul Hakim G. Nusantara, Luhut M.P. Pangarimbuan, Mas Achmad Santosa, KUHAP: Kitab Undang-undang Hukum Acara Pidana dan Peraturan-Peraturan Pelaksana (Jakarta: Jambatan 1986) p. 163ff.

${ }^{22}$ Amnesty, Prisoners of Conscience, and then Tapol, Muslims on Trial, set out to provide a comprehensive review of the trials. Other English language sources-notably Indonesia News Service monthly Logs-supply important details concerning individual cases. Indonesian court documents, in particular defense team submissions such as, for instance, Team Pembela, Pembelaan Kasus Priok, are of course most valuable.

${ }^{23}$ Tandem trials were arranged to overcome difficulties of procedural law and to help the prosecution secure convictions. In criminal cases, the evidence of a single person is insufficient: KUHAP (Articles 183 and 185 clause 2) requires at least a second item of proof. The most convenient form is corroborating testimony. Though a witness must answer all questions put to her/him (Articles 160 clause 3, and 165 clause 1), the accused may elect to persevere in silence (Article 175). This is the nub of the problem for prosecutors. The solution is to hold two trials at the one time. The defendant in one case can be cited as a witness in the other, and vice versa. This creates chances for self- or mutual incrimination. See Tapol, Muslims on Trial, p. 23.

${ }^{24}$ Amnesty, Prisoners of Conscience, p. 22.

${ }^{25}$ See, generally, Team Pembela, Pembelaan Kasus Priok.
} 
Some of the twenty-eight young men charged with armed resistance denied that they had taken part in the demonstration. All those who had marched said they had carried no weapons: some were injured in the affray and some were still noticeably suffering. One had been presumed dead: his family had heard nothing of his detention. The Tapol report notes an absence of prosecution witnesses willing or able to identify any of the twenty-eight, but nevertheless, the judges sent them all to jail for periods ranging from fifteen months to three years. ${ }^{26}$

The four young men from Malang who had been arrested after bomb outrages in that city and at Borobudur were eventually interrogated and sentenced on matters more related to their participation in an Islamic educational network. Other participants in the crash course network were to confess to involvement in the planning and execution of the bombing offences. The admissions of two of these men ${ }^{27}$ served in the conviction of the first four defendants to jail terms of 8 and 15 years. This shows the use in prosecution argument of guilt by association.

Some among the preachers showed lofty scorn for all of the proceedings against them, refusing the legal aid provided in the court and dismissing the services of counsel as pro forma farce; one would not recognize that the court was competent to try him; 28 and others challenged the validity of the law which they were accused of having broken. There were no confessions and few admissions of guilt. ${ }^{29}$ Some preachers, however, accepted both the jurisdiction of the judges and the principles of the national ideology. 30

In his demurrer, Haji Fatwa challenged the legitimacy of his arrest. He explained how the prosecution officers were originally baffled in their search for a plausible indictment and how this had been resolved on their discovery that he had facilitated preparations for the protest meeting at which the Lembaran Putih had been drawn up. Against the accusation that he had conspired to undermine the state he pointed out that his prayer-house, where he was alleged to have plotted, stood always open to the public and that, through long association, he was on familiar terms with the intelligence officers assigned to keep him under surveillance. He would have been a most incompetent plotter. He complained that he had been denied access to his legal advisers, a right guaranteed "at every moment" under KUHAP (Article 70 clause 1). The ministerial regulation $^{31}$ which had reinterpreted this to mean "at every moment during normal working hours" allowed administrators to flout the clear intention of the legislation. Haji Fatwa

\footnotetext{
${ }^{26}$ Tapol, Muslims on Trial, pp. 25-31.

27Mohammad David Frans and Mohammad Achwan (ibid., p. 80).

${ }^{28}$ Hasan Kiat in his pleidooi (defense statement), 1985, p. 97ff.

${ }^{29}$ In the second month of his trial, Tony Ardie changed his plea to guilty and threw himself on the mercy of the government. See Tapol, Muslims on Trial, p. 6. Three years after his arrest (two years after his conviction), Salim Qadar acknowledged that he had been at fault. See Tempo, April 4, 1987.

${ }^{30}$ Fatwa, for instance, and Mawardi Noor. They contested only the requirement for universal and unqualified assent among the formal associations of the nation. See Amnesty, Prisoners of Conscience, p. $5 \mathrm{ff}$., and Tapol, Muslims on Trial, p. 57ff. For challenges to the validity of the law and the competence of the court, see Amnesty, Prisoners of Conscience, p. 20ff. and Tapol, Muslims on Trial, p. $44 \mathrm{ff}$.

${ }^{31}$ Peraturan Menteri Kehakiman M. 04-UM.01.06, tahun 1983, (Article 20) cited in 't Hart and Nusantara, Hukum Acara Pidana, p. 27. Article 20, as reproduced in Nusantara, Pangaribuan, and Santosa, KUHAP, p. 364 , does not use the expression, "normal working hours": it simply places the discretion to arrange visits in the hands of the head of the National Detention Center (RUTAN). See the comment of Senior Advocate Andi Zaenal Abidin, in Abdul Hakim G. Nusantara, Luhut Mp. Pangarimbuan, and Mas Achmad Santosa, Studi Kasus Hukum Acara Pidana (Jakarta: Jambatan, 1986), p. 67.
} 
complained that witnesses had been intimidated: one man who had lied about himunder the pressure of pain-later sought his pardon. But Fatwa was himself to experience physical suffering. When his trial began on August 12, 1985, after long administrative delay, the prosecution case was in jeopardy: there was a strong chance that it might not be completed before the time allowed by KUHAP. Thereafter the government might be compelled to release him. So, despite his manifest illness, the judges required him to attend and endure long sittings. He was obliged to continue reading into the court record the defense plea which he had prepared-until he lost bowel-control.

The records of Sanusi's trials have given rise to two serious charges against the Indonesian authorities. Both charges concern a witness whom (it has been suggested) the prosecution planned to use. In the first trial, where the plan was a last-minute expedient to rescue a collapsing case, there exists prima facie evidence of perjury. In the second, where, despite planning and intense persuasion, a perjury was avoided, there is a statutory deposition indicating that a witness was murdered.

Haji Sanusi had been charged with subversion, inasmuch as he was alleged knowingly to have supplied funds to the terrorist bombers in Jakarta. Midway through the trial, prosecution witnesses withdrew their previous depositions, leaving a considerable gap in the government case. A surprise new witness, Amir Wijaya, was then introduced. According to Tapol: 32

[H]e had not been mentioned in the prosecution's ... list ... at the commencement of the trial. So sceptical [were the defense lawyers] about the date and the circumstance of Wijaya's arrest that they made enquiries about the prosecution's assertion.... [T] he prison had no record of him. Nor [ha]d the prosecution submit[ted] ... Wijaya's pre-trial interrogation [report]....

Sanusi ... denied Wijaya's account of a visit allegedly made to Sanusi at his house on the afternoon of 8 October. The defence later produced an air ticket proving that Sanusi [ha]d not returned until late that evening from a ten-day visit to Japan....

In the second trial, Sanusi was accused of having conspired to assassinate the President. He was found guilty and sent to prison for twenty years, the sentence to be served concurrently with the nineteen year term imposed by the judges in the first trial. In this trial, however, I am concerned with a reluctant witness, Muhamad Djabir bin Abubakar-the intended perjurer, it is alleged-who never came to court. It was instead his nephew's affidavit which came before the judges. The young man's sworn testimony indicates that his uncle, Muhamad Djabir, died as a result of torture. His interrogators had pressed him to implicate Sanusi. Apart from the old man's commitment to honor and veracity-a strong commitment, according to the nephew-there was a further, bizarre, moral complication for Muhamad Djabir. He had never met Sanusi. He should not perjure himself even to save his life (the uncle is reported to have said) and he would not condemn a non-acquaintance. He would rather face death and the severe, but just, judgment of God. Muhamad Djabir died. His body, according to his nephew's testimony, bore the marks of beatings. ${ }^{33}$

General Dharsono used his trial, which opened in September 1985, as an opportunity to press for the investigation which had originally motivated the drafting of the Lem-

\footnotetext{
32 Tapol, Muslims on Trial, p. 76f.; cf. p. 61.

33 Ibid., pp. 86, 104-6.
} 
baran Putih. The court functioned as a forum for de facto public hearings about the confrontation on the night of the march. It gave scope for the public expression of alternative accounts. This summary is concerned, however, with suggestions of procedural irregularity in the trial itself. One of Dharsono's first moves was to challenge the manner of his arrest. Summoned under a pretext, he had been detained by the special military Command for the Restoration of Security and Order (Kopkamtib). The Command had once exercised a power of arrest but, in 1983, at the end of a two-year phasing-in period provided under KUHAP, this competence had been withdrawn. Dharsono was told that it was too late, that this objection should have been raised at an earlier stage, in pre-trial hearings. The judges were loath, it seemed, to enter into any consideration of validityquestions of wrongful arrest, mistrial, improper evidence, incompatibility or incoherence among laws, or any other legal technicality - that might conceivably give grounds for Dharsono's discharge. They had to decide whether the Lembaran Putih was sound or subversive. The defense lawyers sought repeatedly to have a police officer summoned to give evidence. This man, Lieutenant-Colonel Ismet W., was Head of the North Jakarta Police Station. He did not, however, respond to the summons. He was "ill," "recuperating," "on leave," "in Bandung," and, finally, "transferred to North Sumatra." The Presiding Judge, Sudiyono, explained privately to one of the defense team that its insistent pursuit of Ismet had been an embarrassment to the bench. ${ }^{34}$

Although the bench was reluctant to encourage analysis concerning the validity of the anti-subversion law, it did concede the existence of widespread public doubt. Once again it referred doubters to another arena (the legislature, this time), so shelving the issue of its own competence. The interpretation of the question is particularly vexed by the extremely vague and open wording of the law. It was no defense for Dharsono to claim that he intended no subversion. Nor would it suffice for him to show the harmless outcome of all his acts. The prosecution had to establish one thing only, namely: possibility. If one of his initiatives could inflame, could lead to violence, that would serve. It would be enough, even, that such an initiative "could have had a negative impact on national unity." 35

Significant problems of procedure arose in the concluding session of the Dharsono trial, as Presiding Judge Sudiyono was reading out the findings of the court. ${ }^{36}$ Judge Sudiyono saw fit to reproach the defense lawyers for the conduct of their case, saying that their reflections on the motives of the government were "improper and unethical."37 Provoked by this criticism, the leader of the defense team interrupted. ${ }^{38}$ A security officer on guard outside the court entered, ostensibly to restore order. The defense leader told him at once to leave, saying quite correctly that responsibility for order lay with the judges. The incident would later generate much discussion about proper conduct of criminal trials and freedom of counsel in defending clients. These problems lead naturally to the question of the nature of Indonesian law itself: how should it be regarded? Is it the local expression of universal values? Or is it better to think of it as the expression

\footnotetext{
${ }^{34}$ Amnesty, Prisoners of Conscience, p. 20; Tapol, Muslims on Trial, p. 39.

${ }^{35}$ Amnesty, Prisoners of Conscience, p. 16-the emphasis is mine. See also Tapol, Muslims on Trial, pp. 44-45.

${ }^{36}$ On January 8,1986 , General Dharsono was sentenced to ten years in prison, which was later reduced by an appeal court to seven years.

${ }^{37}$ Tapol, Muslims on Trial, p. 51.

${ }^{38}$ The defense counsel concerned maintains that there is precedent for interruption. It could lead to suspension of the verdict and reexamination of the case, as occurred in the trial of Pati Siregar in Medan in the late 1960s (Adnan Buyung Nasution, p.c.).
} 
of a particular national legal culture? These issues are to be discussed in the second section of this article.

In this first section I set out to write a simple account of what happened at Tanjung Priok, but I encountered much contradiction among the reports. Then, in attempting to give a neutral account of the trials, I found allegations of injustice and disputed jurisdiction. So, it proved impossible to provide straightforward description. Yet, in two regards, this material is undisputed: no-one disputes that the allegations have been made, and the Indonesian government has neglected the opportunity to dispute their substance. ${ }^{39}$

\section{Background}

Organizing a cultural hodgepodge into a workable polity is more than a matter of inventing a promiscuous civil religion to blunt its variety. It requires either the establishment of political institutions within which opposing groups can safely contend or the elimination of all groups but one from the political stage. $\mathbf{4 0}$

The question is ... which is to be master? ${ }^{41}$

\section{Explanation}

\section{(A) Disclaimer}

In the years after 1984, two English publications have analyzed the subversion trials. Each has dealt in detail with various legal proceedings. Each has explained the immediate political background to the Tanjung Priok clash. The main task of both documents, however, was to accuse. They listed injustices which they detected from the history of the cases. Appearing, as it were, before the court of world conscience, they have sought to prosecute the Indonesian prosecution.

The analysis offered here aspires to by-pass the question of fault and responsibility: it seeks to avoid recapitulation or elaboration of the immediate political analyses provided in the above documents. Instead, it attempts to explain the clash in Indonesia in terms of various incompatibilities among the myths to which the participants subscribe.

\section{(B) The Function of Myths}

I should explain how I use the term, "myth." A myth is an accepted belief. Whether the belief is false or true is technically irrelevant. ${ }^{42}$ The function of myths is to order the lives of mankind. Every person subscribes at some time to some myths. These are not always easy to identify. The most difficult myths for a person to discern are those which she or he regards as self-evident or necessary truths, as "plain common sense."

\footnotetext{
${ }^{39}$ On three occasions I presented this material to representatives of the government in Jakarta and invited comment on the allegations. I have received no reply.

${ }^{40}$ Clifford Geertz, "Afterword: The Politics of Meaning," in Culture and Politics in Indonesia, ed. Claire Holt et al. (Ithaca: Cornell University Press, 1972), p. 323.

${ }^{41}$ Lewis Carroll, The Complete Works (London: Nonesuch, 1973), p. 196.

${ }^{42}$ Common usage would have it that the word "myth" is only applied to the (false) belief of some other person. The technical definition given here is based on that provided by R. H.C. Davies, The Normans and Their Myths (London: Thames \& Hudson, 1976), p. 16.
} 
Though in many cases the origin of the myth is mysterious, the way it becomes established is more certain. If a myth is to survive, it will require both plausibility and popularity. Once a principle of social action receives sufficient publicity, it is reified as the familiar stuff of discourse. Even argument against its acceptance invests it with hypothetical identity. Terms such as, for instance, "the Caliphate," "ijtihad," "freedom of association," "New Order," and "Pancasilais" can function as much to establish certain social practices-of respect, initiative, sacrifice, or obedience-as they do to proclaim the enduring existence of institutions and ideas. The terms given as examples above do in fact serve to identify some of the deeply seated beliefs-or myths-which are relevant, in greater or lesser degree, to the clash at Tanjung Priok and to the issues of the subversion trials. This will become clear through the essay. Before that, however, it is appropriate to identify the major myths around which such concepts revolve.

\section{(C) Four Central Ideas}

One of the most powerful myths of the twentieth century is the set of beliefs clustered around the concept of the sovereign state. The authority of the state is generally regarded as in one way or another originating from, or expressing the collective will or interests of, its people. One of the chief functions of the state, it is held, is the establishment and preservation of law and order. In that phrase, the latter word, "order," does not augment the meaning of the first. Instead, it explains the sense in which the first is meant to be understood. Law, as the word is used here, functions to ensure regularity in the arrangements of society. Hence, it allows men and women to make reliable estimates of the future. ${ }^{43}$ Those who adhere whole-heartedly to this myth find it hard to conceive that there can be any limit to what the state may regulate. The idea of the unpredictable-the uncontingent-is unbearable to them.

The myth of power is a reaction to the challenge posed by the uncontrolled-that which implicitly or explicitly questions the myth of the sovereign state and threatens the order it would impose. Those who subscribe to this myth hold that might is the only political reality: they would use deceit or violence where appropriate, just as they would use law-as-order, to keep and reassert control.

In contrast to that stands a third set of ideas, those which constitute the myth of justice. This holds that human beings are obliged to behave fairly and that the proper function of government is to protect and promote equal rights among them. It is associated with ideas like the concept of international morality and the rule of law. Note that the concept of law-as-justice may be distinguished from the previous concept of lawas-order.

Another concept which can shape the lives of human beings is the myth of God. Like the other myths, it forms a focus for dependent or derivative ideas around which claims of privilege and imputed obligations can cluster. The following paragraphs will set out various understandings held about God, particularly among the adherents of Islam. Chief among these is the myth of Allah's sovereignty. ${ }^{44}$

\footnotetext{
${ }^{43}$ This is one of the major contributions to the theory of law made by H.L.A. Hart. See his The Concept of Law (Oxford:Clarendon Press, 1970) particularly p. 27f.

${ }^{44}$ The reader will remember that to write of Allah or of His omnipotence as myth is not to reflect, in any way, on the truth or validity of metaphysical propositions about His existence or His attributes. I mean to assert two
} 
Three of these myths - those of the state, of justice, and of God-can claim absolute commitment from human beings. Such commitments are not always readily reconciled. In late 1984 their incompatibility became conspicuous and found violent expression in the dockland streets of North Jakarta. The subversion trials of the following years have functioned as a forum or a kind of theater in which actors with different loyalties have sought to rationalize before the public the various parts they played.

\section{Myths of the New Order State}

The present set of authorities in the Indonesian state is commonly identified as the "New Order" (Orde Baru or Orba). Having its origin in the events of October 1, 1965, when six senior officers of the Indonesian army were murdered in Jakarta, the gestation of the New Order took slightly less than three years. Its development quickened when, on March 11, 1966, General Suharto secured a certificate of authority to take all steps essential for the restoration of security and order. This provided a formal legal basis for the extraordinary powers which Kopkamtib was later to enjoy. ${ }^{45}$ Suharto, a careful and competent administrator, retained the leading role until, on August 17, 1968, he was formally and fully installed as President of the Republic. In the intervening years he had accomplished two major tasks of transition. The Indonesian Communist Party had been declared illegal and disbanded, and the previous president, Sukarno, had been eased out of office. Both achievements have been represented as the results of sacrificial acts of national redemption.

Taking any of the above dates for time of genesis, the New Order can be reckoned as over twenty years old. Several features have characterized it as a governing establishment. Apart from the abiding personal presence of President Suharto, it has been marked by the high profile of military personnel in areas of government conventionally occupied by civilians. These two features develop precedents set up under the previous establishment, the Old Order when the armed forces had spread their services in civil functions and Sukarno had been the main-though not unrivalled-center of power. The two governments share a further characteristic in their state ideology. Both have proclaimed the Pancasila, the national state ideology, as a set of principles which all Indonesians should affirm. Both have proclaimed their own interpretations as revealing the essential message of the Pancasila. Both have discouraged "deviant" analyses of its meaning. The remaining features, however, distinguish the New Order from the Old. The New Order has appointed and promoted "technocrats," that is persons best trained to manage the economic transformation and material growth of the nation, to positions of influence. And, in contrast with the governments of the immediate postcolonial period, it has eschewed the politics of ideological excitement.

Neither Suharto's New Order nor Sukarno's Old Order establishment of Guided Democracy seems to have been comfortably convinced that the myth of national identity was rooted to a sufficient depth in the consciousness of citizens. Ideally, the concept of

things only: that some men and women believe in some of these propositions and that they order their lives in consequence of these beliefs.

45President Sukarno had issued instructions to restore security and order soon after the killings in October 1965. This was the time in which Kopkamtib began to take shape. Julie Southwood and Patrick Flanagan, Indonesia: Law, Propaganda and Terror (London: Zed, 1983), describe the uncertainty which surrounds its origin: what is certain, as they say, is that Sukarno's letter gave Suharto great authority to carry out the prime function of the Command. 
nationality ought to be so strong and so familiar among the people that the state (as established) is proof against any conceivable challenge to its authority or its constitution. Yet those who exercise power (call them the governors) fear that the loyalty of the citizens is not absolutely dependable, and they can conceive of plausible or persuasive alternative ideologies. They fear that, should the polity be subjected to drastic stress, the fundamental concept of sovereign authority would alter. The sacred texts would be replaced: new interpreters would legitimate new governors in terms of new myths. ${ }^{46}$

\section{The Uncontingent}

\section{(A) The Contrast with Civil Religion}

The Uncontingent is the idea which threatens the Indonesian establishment as it threatens every establishment. It is a myth which proclaims that human beings have duties which transcend the interests of the nation; it limits the authority of the state. The myth of the Uncontingent is a concept of transcendent religion, as opposed to "civil religion" which functions to reinforce obedience and conformity to the myths of society. 47 For the true believer, the Uncontingent is the greater myth. It is that which justifies civil disobedience: it confirms the commitment of the dissident, even to the point of death.

This article has to deal with two major myths-justice, and the omnipotence of Allah. Both set limits to the state's sovereignty. So both exemplify the myth of the Uncontingent. Concerning each, members of the New Order establishment might feel unease. The idea of abstract justice, having fewer followers in society and lacking terrible sanctions in its mythology, is probably the less disturbing: ${ }^{48}$ consideration of its claims can be postponed till later. Those of Allah will not wait.

Most New Order supporters would regard themselves as Muslims, yet they would perceive enthusiasm for Islam as a threat; looking with dismay at any deep or regular expression of zeal for the Faith in public life. ${ }^{49}$

(i) A History of Political Aspirations:

In their perception of religious zeal, members of the New Order are heirs to an established tradition. Islam has been the counter-culture of Indonesia for decades, if not for centuries. ${ }^{50}$ The Old Order inherited and passed on, more or less intact, an attitude of

\footnotetext{
${ }^{46}$ Evidence abounds from many cultures that the exegesis of the sacred texts constitutes a key to power and privilege. In the early history of Islamic civilization, for example, men recognized that ideas could endanger the established government. See for one instance, W. Montgomery Watt, The Formative Period of Islamic Thought (Edinburgh: The University Press, 1973), p. 171ff. For a reference to the rhetoric of Indonesian nationalism as "sacred scripture," see Susan Selden Purdy, Legitimation of Power and Authority in a Pluralistic State: Pancasila and Civil Religion in Indonesia (Columbia: University Microfilms International, 1984 ) p. 56.

47 The concept of civil religion is explained in Purdy, Legitimation of Power. See also "Civil Religion in America," in William G. McGloughlin and Robert N. Bellah, Religion in America (Boston: Houghton Mifflin, 1968), pp. 3-23.

${ }^{48}$ The New Order may have attempted to co-opt the values of abstract justice-equity (pemerataan) and the rule of law (as negara hukum) -in its program of ideological sedation.

${ }^{49}$ There is a simple gauge of this-New Order opposition to the cult of the Ayatollah Khomeini. For example, the terrorist group that detonated the bombs in East Java was identified with Shica "heresy" (Indonesia Reports: April Log No. 7, A pril 23, p. 40f.); Major-General Soelarso had identified the group with "an extremist wing . . . in the Middle East," ibid., April 29, p. 53.

50 Apart from its role vis-a-vis the Dutch imperial authority in the Archipelago, Islam also came to function as a useful ideological option for many traditional rulers: its claims were invoked or shelved in accordance with
} 
suspicion towards Islamic enthusiasm. In the late colonial period, the Dutch administration adhered to a policy of containment. There were two aspects to this policy. Enthusiasts had no access to the civil power necessary to realize what they believed to be the ultimate purpose of social life: governors did not interfere with the devotional practices of Muslims. The containment policy developed partly in reaction to the international ideological renovation which Islam had experienced after about AD 1880 during the opening decades of the fourteenth Hijra century.

The experience of foreign domination during the previous hundred years had led many of the colonized peoples of Asia and Africa to analyze their situation and search for the fundamental errors which had made their subordination possible. Among Muslims, one ready answer was insufficient devotion to the Faith. From this explanation it was a comparatively easy step to marshall the dissatisfied, to inspire them to rededication, and to lead them to martyrdom in the attempt to alter the existing order. The Mahdist movement in the Sudan is one example; another, from Indonesia, is the Peasants' Revolt in Banten in 1888.51 These attempts failed. A more sophisticated analysis emerged from the polemics of the late nineteenth century Islamic apologist, Jamal al-Din al-Afghani, 52 who offered a new myth. This was a vision of a dynamic Islam, capable of accepting the novelties of scientific discovery and of incorporating technological change within a world civilization which recognized the sovereignty of the one God and, without contradictions, conformed to the words of His revelation. This vision for the new age was presented as a revival, ${ }^{53}$ a recovery of the attitude which had inspired the Islam of the first caliphs. Jamal argued, as did the Egyptian theologian, Mohammad cAbduh, 54 for the reopening of the "Gates of Ijtihad." That is to say that liberty of thought under Islam ${ }^{55}$ ought to be recognized and that the free play of reason should be encouraged. Muslims should be released from slavish obedience to those conventions which had been sanctified only by the passage of time. In place of obedience they should accept the obligation to think about the application of their faith to the problems of the changing world. This would amount to a restoration of ijtihad, and with it would come the initiative and inventiveness which had characterized the civilization of the first believers. Then the secular nation states of western Europe, animated mostly by material considerations and the myth of (imperial) power, would be left behind by a rejuvenated Islamic world society.

the dictates of administrative expedience. Sce W.F. Wertheim, Indonesian Society in Transition: A Study of Social Change (The Hague: van Hoeve, 1959), pp. 195-204.

${ }^{51}$ See, for details, Sartono Kartodirdjo, The Peasants' Revolt of Banten: Its Conditions, Course and Sequel (The Hague: Nijhoff, 1966).

52 On Jamal al-Din al-Afghani, see Albert Hourani, Arabic Thought in a Liberal Age 1798-1938 (Cambridge: Cambridge University Press, 1962), pp. 103-29 or C. C. Adams, Islam and Modernism in Egypt (New York: Russell \& Russell, 1933) pp. [4]-17.

${ }^{53}$ See the definition of revival given in C. A. O. van Hieuwenhuijze, Aspects of Islam in Post-Colonial Indonesia (The Hague: van Hoeve, 1958), p. 23f.

${ }^{54}$ On Mohammad 'Abduh, see Hourani, Arabic Thought, pp. 130-60 or Adams, Islam and Modernism, pp 18176.

55 This is a simple summary of the renovations which they were concerned to advocate. A thorough analysis of the reformers' program would reveal the difficulties in the formula: there is an obvious tension between the ideal, "liberty of thought," and the saving phrase, "under Islam." For a careful statement of the problem, see "Sikap 'Islam' terhadap 'Kemerdekaan Berfikir" in Mohammad Natsir, Capita Selecta, I (Bandung/The Hague: van Hoeve, 1954), pp. 206-29. 
That Pan-Islamic vision stimulated both the formation of the containment policy and the anti-imperialist struggle of Muslims in the Dutch East Indies. ${ }^{56}$ In the second decade of this century a mass anti-colonial organization functioned under the loose label of Islam, but its ideas were derived as much from international socialism as they were from the Qur'an. In the 1920s the ideological incompatibilities became explicit; the movement split. The way was clear for the full development of a myth of Indonesian nationhood. Sukarno, among others, ${ }^{57}$ advocated that nationalism should become the central concept: it would accommodate the objectives and energies of anti-colonial Marxists and Muslims. Among the latter, Sukarno's program had little appeal: those still inspired by the reforming visions of Jamal and 'Abduh had another goal.

The reformers had created scope for their fellow believers to accommodate the scientific, medical, and technical inventions of European civilization. But many so-called Modernists were reluctant to adopt another contemporary European invention, the nation-state. They examined this concept in the light of Islamic fundamentals and found it wanting, considering the idea of any ultimate state, other than the dar al-Islam, to be repugnant. The dar al-Islam (which means something like ${ }^{58}$ "the realm of submission") is the utopia of Muslims; it is the myth of a society functioning in perfect conformity to the revealed law of God. That men should ascribe sovereign power to institutions founded and administered by mortals like themselves was, for the Modernists, a challenge to the authority of Allah. Their religion taught them that ultimate sovereignty belongs to God. It would be blasphemy to recognize it in any part of creation. The Modernists recognized, of course, that ethnic and linguistic distinctions were natural facts. They could allow that a nation might exist as a temporal expedient in an imperfect world. This would represent, ideally, an interim stage on the way to realization of the dar al-Islam. But, from their perspective, reverence for a sovereign state would lead, almost inevitably, to shirk (idolatry), the worst sin of all and root of every other human failing.

The reformist myth: that human society can be perfected under the aegis of Islamcarries a corollary: that no other organizing principle can achieve this. Together they provided a program for Muslims opposed to the Netherlands government of the East Indies in the twentieth century. They had a duty to work for the realization of this ideal. $^{59}$ During the last decade of unchallenged Dutch administration (the 1930s) they achieved little progress-those who accepted the nationalist vision did little better. Thereafter, however, both groups gained great opportunities-and the Muslims received more encouragement. The Japanese military government of occupation valued the potential contribution of Indonesian Muslims in the war effort against the Euro-American alliance. They encouraged the organization of political Islam and approved its mar-

\footnotetext{
${ }^{56}$ See the discussion in George McTurnan Kahin, Nationalism and Revolution in Indonesia (Ithaca, N.Y.: Cornell University Press, 1952), pp. 44-49.

57 For the other nationalists with their other programs, see the discussion in ibid., pp. 87-93.

58 The Arabic words allow manifold translations-abode of peace, house of Islam, area of resignation, and others. The exact meaning of the term is further confused by the use of the name, Darul Islam, for rebellions motivated by the idea of an Islamic state in three separate Indonesian provinces after independence.

${ }^{59}$ See the discussion in Howard M. Federspiel, Persatuan Islam: Islamic Reform in Twentieth Century Indonesia (Ithaca, N.Y.: Modern Indonesia Project, 1970) pp. 84-96 or Wertheim, Indonesian Society in Transition, p. 221: "[The] task now was to prove that the Islamic ideology was supcrior to all other ideologies and was the real source of all that is good in the world."
} 
tial expression. ${ }^{60}$ The Pan-Islamic vision, though in principle a greater danger to their own imperial designs, offered a less immediate threat than did the goal of independent Indonesian nationhood. The Japanese, while still not masters of the world, might risk lip service to the concept of Islamic civilization: they could not be expected to deliver yet. They had to be more cautious with regard to local loyalties: the patriots might one day want the occupying power to go away.

In the months after March 1945, as Japan, on the edge of defeat, sought immediate or long-term future allies among Indonesians, leaders representing differing political persuasions met to prepare the myths for an independent Indonesia. 61 For this article, the major issue of that debate was the extent to which the nascent polity was to be explicitly Islamic. Muslim enthusiasts argued that the organization and administration of the state ought to reflect the convictions of the overwhelming majority. ${ }^{62}$ Opposition came variously from the Christian minorities, from advocates of more materialistic international ideologies, and from adherents to different indigenous regional political traditions. The essential task was to find the right form of words in which to cast the myth of a postJapanese non-Dutch state in Indonesia. In the conditions then obtaining, any form of words at all would have been bound to alienate some one or other among the groups of potential supporters. So, the leaders' search for the right formula was a quest for the optimal myth, the one which would exclude fewest and satisfy most. It had, above all, to secure the cooperation of those groups whose participation was judged essential for the delivery of the nascent state. The leaders-the Founding Fathers of the Republic of Indonesia-tested three formulae and fixed on one. It is the Preamble to the Constitution. Although this story has been told frequently and well, ${ }^{63} \mathrm{I}$ must repeat it here in summary: I have to show the origin of a stress which enthusiastic Muslims have endured through forty years of independence.

(ii) A Formula with Five Principles:

On June 1, 1945, the Preparatory Committee for Indonesian Independence heard Sukarno expound five principles, the Pancasila, as the culmination of their long and difficult deliberations. These five sila have often been characterized as "secular." This is misleading. They neither were nor are. They functioned then as an optimal (or "right") formulation, in an attempt to establish a sparsely furnished midway place of accommodation on various axes between:

\footnotetext{
${ }^{60}$ This characterization of the overall tendency of occupation policies is derived from Harry J. Benda, The Crescent and the Rising Sun: Indonesian Islam under the Japanese Occupation 1942-1945 (The Hague: van Hoeve, 1948), p. 178ff. The judgements of non-Islamic nationalists are reported in C. van Dijk, Rebellion under the Banner of Islam: The Darul Islam in Indonesia (The Hague: Nijhoff, 1981) p. 63.

${ }^{61}$ These leaders met in the Investigating Committce for the Preparation of Independence (Badan Penjelidik Oesaha Persiapan Kemerdekaan) founded on March 1, 1945. See descriptions in Kahin, Nationalism and Revolution, pp 121-27 or Benda, Crescent and Rising Sun, pp. 188-91.

${ }^{62}$ The convention is to cite 90 percent-that is to say that nine out of ten Indonesians are Muslims. Deliar Noer, The Modernist Movement in Indonesia 1900-1942 (Singapore: Oxford University Press, 1973) p. 3, n. 3 offers detailed comments on this convention.

${ }^{63}$ For example Benda, Crescent and Rising Sun, pp 188-91, Kahin, Nationalism and Revolution, pp. 121-27, B. J. Boland, The Struggle of Islam in Modern Indonesia (The Hague: Nijhoff, 1971) pp. 15-39, Bernhard Dahm, Sukarno and the Struggle for Indonesian Independence (Ithaca, N.Y.: Cornell University Press, 1969), pp. 33643, van Dijk, Rebellion under the Banner of Islam, pp. 45-64.
} 
the poles of chauvinism, xenophobia, and fascism on the one hand and an undifferentiated cosmopolitan collectivism on the other. (This was the function of the first two sila, as propounded by Sukarno)

the poles of populism and mob rule on the one hand and the expertise of an elite group of governors on the other. (This was Sukarno's third sila)

the poles of personal property rights as the reward for initiative on the one hand and the claim to equal distribution of goods among all members of society on the other. (This was Sukarno's fourth sila)

the poles of opposition between domination by Islamic enthusiasts-the advocates of the dar al-Islam -on the one hand and a godless, ethically indifferent secular state on the other.

Sukarno left this sila, which was to become an item of continuing contention, till last. It is the important sila for this essay. The wording proposed and adopted was $\mathrm{Ke}$ Tuhanan Yang Maha Esa. Literally, this phrase means something like ${ }^{64}$ "the essential Godhood of the One Who is supremely one." It has been subject, however, to a variety of interpretations-ranging from uncompromising theism (as proclaimed by the Semitic religions of revelation) to tacit assent for metaphysical monism (more characteristic, perhaps, of ancient Indo-Javan beliefs). Though these interpretations are germane to the conflict between the myths-the Uncontingent and the State-all that need be noted here is that the formula, Ke-Tuhanan Yang Maha Esa, would serve to hold and justify the support of Muslims. The Pancasila program fell far short of the dar al-Islam but the fifth sila seemed to affirm their fundamental belief, monotheism. It would suffice. So, the representatives of Islam unhappily accepted 65 the five principles as the basis for the common struggle.

Almost at once, the issue-official recognition for Islam-re-emerged. The second formula, which came to be known as the Jakarta Charter, incorporated the Pancasila: the five principles were rephrased and reordered. Ke-Tuhanan led the list: "the Republic of Indonesia is founded on ... the principle of deity, with the obligation to put the law of Islam into practice for its adherents ..." (Please note that the Indonesian original of the italicized phrase consists of seven words. ${ }^{66}$ ) The leaders would have needed considerable

\footnotetext{
${ }^{64}$ As was the case with dar al-Islam (see above), the term, Ke-Tuhanan Yang Maha Esa is susceptible to various translations. Tuhan is an indigenous word for God: the affixation, ke+ with +an, serves to indicate, among other possibilities, the abstract quality of the embedded word. Yang, a word which could be used for reference to deity, may be glossed here as: "the one who..."; or "he who..." Maha is an intensifier, meaning roughly "paramount" or "supremely" and Esa means "one" or "sole." See the discussion in note 72 on p. 38 of Boland, Struggle of Islam. See also the explanation given by T. B. Simatupang, "This is My Country" in International Review of Mission 63, No. 251 (July 1974) p. 317 ("the ... principle is not belief in God' but rather is 'the idea of Lordship'...").

65"unhappily accepted"-The impression created by Sukarno, Lahirnya Pantja Sila (Jakarta: Ministry of Information, 1960) and official Indonesian propaganda generally has been that this formulation represented a resolution of the problems vexing the founders of the nation. However, Boland, Struggle of Islam, p. 23 creates a different impression. Far from resolving the problem, Sukarno's speech-under Boland's interpretationbrought the difficulties clearly into the open: in this light, his achievement in formulating the Pancasila was the creation of a framework within which dialog could be held. Later, as the essay will show, the Pancasila were used for other purposes.

${ }^{66}$ Dengan kewajiban menjalankan syariat Islam bagi pemeluk-pemeluknya. It is not certain whether the obligation (kewajiban) rests on the adherents (pemeluk-pemeluk) or on some other unnamed agent (the government?). Again, as Boland has noted (Struggle of Islam, p. 31 or van Dijk, Rebellion under the Banner of
} 
time to convince Christians, Nationalists, and other non-Islamic factions of the harmless intent of this phrase. But time ran out. The sudden surrender of Japan (August 15) and the consequent Declaration of Independence two days later left little time for negotiation. On August 18 Vice-President Mohammad Hatta (himself a dutiful follower of Islam) successfully persuaded Muslim members of the new Preparatory Committee that it was necessary to delete from the draft constitution three potentially divisive provisions, to wit:

that Islam was to be the official religion of the state,

that the President would have to be a Muslim,

that an obligation existed to implement Islamic law (i.e. the seven words qualifying ke-Tuhanan in the Jakarta Charter).

In this way all explicit mention of Islam disappeared from the official documents: the amended charter became the Preamble of the national Constitution. That, the third formula, was fixed.

(iii) Disappointment:

So, the Founding Fathers enshrined several myths-of nationhood, of the Pancasila, of the Constitution, and of union in the common struggle (the myth of the 1945 Generation). At the same time, inevitably, they created a different sort of myth for Muslims: Islam had been refused its proper place within the new state. Disaffection, an attitude left over from the colonial era, was reinforced by disappointment: Muslims had sensed that power was within reach when, in the early months of 1945, it was slipping from the hands of their Japanese sponsors. Then, as a consequence of treachery or incompetence, or both, it was denied them. The community of Islam has interpreted its history through the post-independence years in terms of this myth.

The myth of disinheritance became a motive, or provided the pretext, for various violent expressions of Islamic militance. The most notable of these were three regional rebellions which, through the 1950s and into the 1960s, sought to establish the ideal Islamic polity in their separate locations. ${ }^{67}$ Each movement identified itself as Darul Islam. The Armed Services of the Republic were to be engaged in protracted counterinsurgency campaigns against them. ${ }^{68}$ Nevertheless, in the initial stages, members of the major Islamic party, Masjumi, were equivocal in condemning the rebels. This is background to the Tanjung Priok trials.

In the late 1950s, the Darul Islam received comfort from other rebellions, which broke out principally in West Sumatra, a strongly Islamic area, and in the largely Christian Minahasa region of North Sulawesi69 A counter-government (Pemerintah Revolu-

Islam, p. 400, n. 37), the verb, menjalankan, can carry many meanings. See Boland, Struggle of Islam, p. 27, for another interpretation.

${ }^{67}$ The three regions were West Java, South Sulawesi (which promoted dependent uprisings in other smaller island regions in eastern Indonesia), and Acch (North Sumatra). Darul Islam rebellions also took place in Central Java and South Borneo.

68 The rebellions were stamped out during 1962 (in West Java and South Borneo) and 1965 (in South Sulawesi): the last guerrillas surrendered in Acch in 1962. Most of the other problems connected with Darul Islam had been resolved in the 1950 s.

${ }^{69}$ This was the Permesta affair. For full analysis, see Barbara S. Harvey, Permesta: Half a Rebellion (Ithaca, Cornell Modern Indonesia Project, 1977). 
sioner Republik Indonesia-PRRI) was proclaimed in West Sumatra, with some prominent Masjumi parliamentarians as leaders: three ex-prime ministers-Mohd. Natsir, Burhanuddin Harahap, and Syafruddin Prawiranegara-were among them. By this stage the Masjumi had become for some time the sole effective political expression of reformist Islam in Indonesian public life. When the counter-government failed, the Masjumi, having incurred corporate guilt through the actions of individual members, was outlawed. So, the reformists lost the little influence they may have had with the governors under the Old Order.

The regional rebellions ended before the New Order was conceived. Nevertheless, the alienation which they expressed has persisted under the present establishment. By not rehabilitating the Masjumi, the New Order disappointed many people. Ex-members have been allowed to fulfil certain roles in social and religious life, but they have had to avoid all participation in the formal political process. They have tended, consequently, to associate with the informal opposition groups in Indonesia. The three former prime ministers endorsed the Petisi $50^{70}$ and Syafruddin Prawiranegara became the General Chairman of the Korps Mubalig Indonesia (KMI-Preachers' Corps of Indonesia). His deputy, another ex-Masjumi parliamentarian, was the preacher, Mawardi Noor, who was arrested on September 14, 1984..$^{71}$ This history of violent opposition to the Republic provides background for the diffidence which New Order beneficiaries and the otherwise unconcerned public display when enthusiasts confront them with demands made in the name of Islam.

(iv) Another View of Islam and Society:

In recent years, however, younger Indonesian Muslims have exercised the option of ijtihad. One idea emerging from their studies, thought, and discussion has been a doubt that Islam makes any claim to statehood. These young men have taken the central problem of this century - the failure of Muslims to realize the ideal polity-and have relocated the dar al-Islam in the heart of the individual human being. ${ }^{72}$ For them, this is the essential message revealed through the Prophet: Islam is right relationship of creature to Creator. Socially considered, Islam is a community of believers, a kind of civilization manifest under a variety of human-and, therefore, imperfect-governments: all that this civilization requires for its people is the opportunity for worship and performance of duties. The state, under this view, has been called into existence to establish and maintain a social order that allows mankind to achieve the good life. This includes both material well-being and freedom for response to God's spiritual initiatives. Temporal governments exercise full powers for that purpose. But such authority is finite: never could it contradict the omnipotent Creator of the universe.

Given this theology, Muslims need strive no longer to institute the dar al-Islam state: it has never belonged to the social agenda. The ideal of the Islamic State is, in fact, a potential idol. ${ }^{73}$ The evils of totalitarian government are made no less severe when reli-

70David Jenkins, Suharto and his Generals (Ithaca: Corncll Modern Indonesia Project, 1984), p. 162.

${ }^{71}$ Tapol, Muslims on Trial, pp. 58f., 64f. Amnesty, Prisoners of Conscience, p. 32, supplies the date of his arrest.

${ }^{72}$ See Boland, Struggle of Islam, pp. 221-24 and, particularly, B. J. Boland, "Discussion on Islam in Indonesia Today" in Koninklijke Nederlandse Akademie voor Wetenschappen, Studies on Islam (Amsterdam: North Holland, 1974), p. 44f.

${ }^{73}$ See "Apologi Negara Islam," in Nurcholish Madjid, Islam: Kemodernan dan Ke-Indonesiaan (Bandung: Mizan, 1987), pp 253-56, "[A] State cannot possibly ... organize and supervize the motivations or the spiritual attitudes of its citizens... And every action directed towards spiritual authority over other persons ... 
gion is offered as the end which justifies its means. The State under any guise should not be worshipped.

This teaching runs against mainstream theories of politics in Islam. Muslims were certainly involved in some way with problems of civil order both in the lifetime of the Prophet and, thereafter, in the era of the companions. Moreover, the orthodox have proclaimed, through the centuries, the unity of this world and the next. ${ }^{74}$ Yet, a volte-face need cause no surprise: revival involves the contradiction of tradition and, on occasions through those centuries, individual Muslims have offered divergent accounts of the foundations of government.

The history of Islamic social theory ${ }^{75}$ reveals a complex web of tensions, continua, compromise positions, and intermediate constructs. It is an oversimplification to present it as a black and white issue which divides enthusiastic Modernists from younger pembaharuan Muslims. The following six propositions constitute a more accurate summary.

that Muslims deny governments any right to obstruct believers in the practice of religion;

that the ideal of a perfect community is deeply rooted in Islamic tradition;

that Islamic enthusiasts desire to realize this ideal;

that some enthusiasts believe violence may be legitimate as a means to this end;

that other conscientious Muslims, aware of the teachings of past and present cobelievers, still remain unengaged in any struggle to establish the Islamic state;

that there remain numerous tenable intermediate positions for Muslims.

\section{Pancasila: The Myth of the New Order State}

To understand the conflict of loyalties which found expression at Tanjung Priok and in the subsequent subversion trials, I must return to the central myth of the nation state, the Pancasila. It is necessary to consider the way in which Indonesian politicians have tried to use the five-fold formula. This history may be viewed as a sequence of four phases.

Each of the Pancasila was susceptible to diverse interpretations. The very vagueness of their wording was a virtue in the struggle for independence-and that openness is the

amounts to competing against God, or practising idolatry," (p. 256). See also Dawam Rahardjo, "A Critical Islamic View of the State" (Sydney University, Paper for the Asian Peace Research Association Conference: Reversing the Dynamics of Militarization in Asia and the Pacific, August, 25-27, 1986) p. 10f.

${ }^{74}$ Madjid, Islam, p. 249, mentions-in the course of the same article ("Menyegarkan paham keagamaan di kalangan umat Islam Indonesia") - the formula, dunia dan akhirat (world and after-life) as the standard Qura'nic targets of the good life. The phrase has often been cited in defense of the proposition that, in Islam, it is impossible to make a separation between what belongs to Caesar and what belongs to God. Consider also the words of Mohammad Natsir: 'There exists in Islam no 'church' in the sense of a separate body ... having a separate existence within the state" ("Sumbangan Islam bagi Perdamaian Dunia," in Capita Selecta II [Jakarta: Pustaka Pendis, 1957], p. 66).

${ }^{75}$ See, for description, Erwin I. J. Rosenthal, Political Thought in Medieval Islam: An Introductory Outline (Cambridge: The University Press, 1968); Malcolm H. Kerr, Islamic Reform: The Political and Legal Theories of Muhammad 'Abduh and Rasshid Rida (Berkeley: University of California Press, 1966); and Ahmad Syafii Maarif, Islam dan Masalah Kenegaraan: Studi tentang Percaturan dalam Constituante (Jakarta: LP3ES, 1985). See particularly the doctrine of darura (necessity) discussed in Kerr, Islamic Reform, pp. 169-71. 
characteristic quality of the first phase. During that campaign, the Pancasila formula functioned as the highest common factor among ideologies, leaving unspoken the mutual contradictions and incompatibilities which threatened to fragment resistance to the Dutch.

Then, after the general election in 1955, ideological differences became sharper. The returns had clearly shown that politically mobilized Islam did not command the overwhelming support of Indonesian voters. There were many parties but there was no single dominant stream. So, during the debates to determine the permanent Constitution in the late 1950s, various politicians tried to interpret the Pancasila in such a way that adversaries were excluded from access to office or generally discredited. Islamic apologists at this stage pointed to the difficulties which they expected Marxists would find in endorsing the concept of ke-Tuhanan. The doctrinaire materialists, for their part, emphasized the Muslims' ambivalence regarding the Darul Islam movements. They suggested that the enthusiasts shared the rebels' commitment to an alternative, alien, ideal-the Islamic state. Leaders from other parties and persuasions (some of them Muslims) joined in this attempt to present the Pancasila as the distillation of native values, the formula for patriots.

During the third phase, the five sila lost their function as a wide and open framework within which contradictory ideas were so loosely held that conflict-and even contact-could be avoided. With the advantage of official support, the Pancasila began to compete against other ideas for the allegiance of Indonesians. Pancasilais became a term of government approval-and bukan Pancasilais (non-Pancasilaist), a pejorative.

Recently, the leaders of the New Order have created an all-including role once more for the Pancasila. They seek that the whole of the Indonesian people should embrace it. This time, however, there is a simultaneous function of exclusion. Contention is to cease. National law now requires all social organizations (organisasi kemasyarakatan) to adopt the five-fold formula as the single sufficient basis of their incorporation. ${ }^{76}$

In phase one, then, the intended function of the Pancasila was: inclusion of the maximum number of people and the maximum number of ideas. (This began in 1945.) In the second phase, politicians employed the Pancasila against opponents to exclude certain people and certain ideas. (This process was well under way in the years after 1955.) In phase three, the Pancasila became the rival of other ideologies. (Though moves towards this end might have been observed during the Guided Democracy era, it has been most whole-heartedly promoted by the New Order establishment in the years since 1965.) In the last phase, the five-fold formula functions in two ways: it includes all the people and

\footnotetext{
${ }^{76}$ The legislation is Undang-undang Republik Indonesia nomor 8 tahun 1985 (17 Juni) tentang Organisasi Kemasyarakatan. Social Organizations are defined in Article 1 as "organizations formed on a voluntary basis by members of the community of Indonesian citizens on grounds of common activity, vocation, social role, religion and belief in the One, Supreme God." Article 2 clause 1 states that Pancasila is to be the only foundation (asas tunggal): clause 2 says that this applies to the life of society, of the nation and the state (kehidupan bermasyarakat, berbangsa dan bernegara). The official Clarification (Penjelasan) says that the word asas embraces all synonyms-dasar, landasan, pedoman pokok, etc. (say, fundamental principle, cornerstone, lodestone, etc.). The clear intention of the Government is to cut off all possibility of resolving crises of conscience by silent reservation or verbal subterfuge. There are just three options for theists who belong to clubs or social groups: they must accept the ideology imposed by law, or they must resign from, or disband, the association; or they must defy the law and choose to belong to an illegal organization.
} 
excludes all the ideas-apart from the national ideology itself. (This development was made law in 1985.)

Alternatively, the last three stages might be seen as one, with the initiatives of the 1980 s as extensions of a practice begun thirty years ago: employing the Pancasila as an instrument to emasculate adversaries. To make good sense, this theory needs one simple hypothesis: that New Order governors still regard organized Islam as a potent rivalthat they expect that Islam, in spite of every difficulty encountered or created for it, could still exert powerful political appeal for the loyalties of Indonesians.

\section{Rule of Law in Indonesia}

\section{(A) Possible Meanings}

"Rule of Law" signifies different conditions for different persons. Consider, for instance, the following sentences:

[T]he rule of law (always uncertain in Indonesia) has become rather firmer ... and

The power of the State in Indonesia worries anyone, within Indonesia or abroad, who is concerned with civil liberties. It is no secret that both civilian and military authorities in Indonesia often exceed their ill-defined authority. . . .

The second quotation follows closely behind the first in an article published by an Australian academic. ${ }^{77}$ It is clear that the writer intended no contradiction. So, for him, "rule of law" signifies something other than respecting civil liberties and accepting limits to state power. The difficulty with the word, "law," is that it covers certain separate, though connected, concepts. ${ }^{78}$ They were mentioned at the beginning of the essay. Now I must distinguish them briefly.

Foremost is the concept of law as the necessary concrete expression of sovereign authority. In this guise, law is the sine qua non of the state. To be recognized as a state, a society must evince the phenomenon of law ${ }^{79}$ and to be recognized as a coherent state, the society must display a comprehensive and self-consistent legal system. The distinctive function of law, under this understanding, is to proclaim and to display the supreme power of the sovereign: 80 this is the myth of the state.

A second concept of law is that it promotes regular life in society. Members of the society need to feel assured that most of them, on most occasions, can make reasonable estimates of future arrangements. People do not willingly engage in unenforceable contracts. So, to the extent that the sovereign (society) is interested in the promotion of col-

\footnotetext{
77 then academic, now civil servant, Peter McCawley, "Travels in Indonesia," The National Times (Canberra), August 23 to 29,1985 .

78The concepts overlap to some degree in any functioning legal culture. In that sense, the distinctions may appear as nothing more than variations in emphases among different aspects of the single entity, law. On the other hand, one concept may be so conspicuous, in a particular legal culture, and another so nearly absent, that they can be discerned as discrete social functions or purposes.

${ }^{79}$ This idea comes from the analysis of S. Diamond, "The Rule of Law versus the Order of Custom" pp. 42-72 in Social Research 38 (1971).

${ }^{80} \mathrm{Cf}$. the wrath of the monarch as presented in Michel Foucault, Discipline and Punish, trans. Allen Lane (London: Penguin, 1977), pp. 48f., 55-59.
} 
lective undertakings, it establishes conventions and backs them with sanctions to reinforce the fulfilment of agreements. This kind of law is an indispensable instrument of commerce and development: it was, apparently, what the Australian economist had in mind when he wrote of rule of law.

Another view holds that, though they are valid, the previous functions must always be subordinate to the prime function of law: the realization of justice. A complex concept, justice is sometimes difficult to determine with precision. Nevertheless, certain basic elements can be indicated. Two axioms of "natural justice"-Audi alteram partem (Hear the other side) and Nemo judex in causa sua (Let no-one arbitrate in her/his own case)-have served to generate specific rules of procedural law. In criminal cases there are certain requirements (for clear and succinct formulation of charges and expeditious arraignment) and certain conventions (presumption of innocence, 81 equal access to evidence, and equal opportunity to examine witnesses)-all of which are held to be corollaries of the first principles. Such rules function, it is believed, to maximize the possibility that the processes of law will result in justice. Total contempt for all of these would bring a legal system into disrepute. The myth of justice is presented in this formula: the officers of the state must secure the law, being bound always to observe equal treatment of like persons and regularity in the decision of like cases. Difficulties arise for the realization of justice, when passage of time, or peculiarity of personal status, give rise to a claim that the government officers are dealing with significantly unlike cases. Justice, then, may oblige them to act in a different way.

If the laws of a state are to be accepted and observed, then the great majority of its people must remain convinced that those laws function to promote justice. They must, at the very least, feel sure that the laws make it impossible for manifestly unjust situations to remain long without remedy. The importance, for the government, of securing this conviction among the people may outweigh the values which it attaches to justice itself. A governor may conceive that it suffices simply to satisfy the expectations of the subject populace. As long as the people believe that right has been established or restored, the governor may safely ignore actual case details or minute considerations of equity. The success of such a policy is to be measured, in its own terms, by the absence of dissidence or rebellion. This teaching might tempt any government to use any expedient means to secure its end, the appearance of justice. That is another interpretation for "rule of law." Some governments succumb to the temptation.

These four concepts-assertion of sovereign power, regulation of social transactions, pursuit of justice, and the pretence thereto-might suffice to interpret actions in any legal culture. Each motive may be present in greater or lesser degree. I suggest, therefore, that there are just two important questions for this essay: "How do these motives figure..." and "Which function is paramount ... in the legal culture of Indonesia?" The answers lie in the history of that culture.

\footnotetext{
${ }^{81}$ This is a Common Law principle. By way of contrast, the Civil Law of France requires the accused to demonstrate her/his innocence. The KUHAP position has been discussed above.
} 


\section{(B) The Legal Culture}

In spite of the explicit revolutionary 82 intentions of its founders, the Republic of Indonesia derived many of its legal values and institutions from traditions established under imperial administration. By the measure of both principles and practices, the Netherlands East Indies did not constitute a coherent state. The Indies had been a plurality of sovereigns, courts, customs, and putative codes. ${ }^{83}$ Predictability and reliability were lacking. There had been attempts to rationalize the laws from 1800 onwards: such initiatives came with greater frequency during the last decades of colonial administration. Mostly they ran aground on the difficulties of multiple jurisdiction: men might attend different courts and face different claims or charges because of nationality, race, religion, or local ethnic identification. The resolution of that complexity has continued with more assurance since independence. ${ }^{84}$

Notwithstanding the strong nationalist tenor of contemporary law, a set of less immediately discernible items, the legacy of Dutch training, remains. These are often inchoate assumptions about the values and functions of law. The oldest tradition, established in the time of the United East India Company, ${ }^{85}$ was a commitment to regular administration of public and private transactions. The practice of the Company's officers was less than regular. ${ }^{86}$ The United East India Company existed for commerce, and its eventual successor, the Netherlands East Indies, has been characterized as a bureaucratic polity (beamtenstaat). The colonial government did not always succeed in maintaining strict separation of the judicial service from other administrative offices: it was doubtful, at most times, that it was committed to the attempt. Administrators from the bureaucracy were frequently required to preside at provincial court sessions-and, as the last resort of power in the colonial era, the Governor-General held extraordinary prerogatives (exorbitante rechten) which allowed him to set aside any judgement of the courts whenever he found it convenient so to do for the good government of the Netherlands Indies. 87

The rights of the individual person became a serious systematic consideration after parliamentary reform in the Kingdom of the Netherlands at the mid-point of the nineteenth century. But, even then, administrative expedience and authority remained important considerations in the practice of colonial law. Records of court proceedings in

\footnotetext{
${ }^{82}$ The Indonesian War of Independence (1945-1949) was revolutionary in this sense, if no other: legal distinctions based on race were abolished from the written law of the post-colonial state. See Daniel S. Lev, "Judicial Institutions and Legal Culture" in Culture and Politics, ed. Holt et al., pp. 253, 257.

${ }^{83}$ Supomo, Sistem Hukum di Indonesia Sebelum Perang Dunia II (Jakarta: Pradnya Paramita, 1982) gives a concise description of this complex of legal systems.

${ }^{84}$ In addition to the criminal procedural code, the Indonesian parliament has enacted national land and marriage laws. A national law on inheritance has bcen foreshadowed. Each of these matters requires ideological or conceptual readjustment among Indonesians. The Government still gives some lip service to the value of customary law. See the Preamble to, and Article 5 of, the Basic Agrarian Law (Undang-undang Pokok Agraria) of 1960. See also the discussion in M. B. Hooker, Adat Law in Modern Indonesia (Kuala Lumpur: Oxford University Press, 1978) pp. 113-18: it shows that, in effect, the provisions of the Act (Article 56, for example) greatly limit the actual force of custom.

${ }^{85}$ See John Ball, Indonesian Legal History 1602-1848 (Sydney: Oughtershaw Press, 1982) or M.B. Hooker, ed., Laws of South-East Asia (Singapore: Butterworth, 1988) pp. 185ff., 255ff.

${ }^{86}$ Ibid., p. 214ff. or Clive Day, The Policy and the Administration of the Dutch in Java (Kuala Lumpur: OUP, 1902) p. 98 , n. 1.

${ }^{87}$ Hooker, Laws, p. 272 f.
} 
the first part of the twentieth century show that the effective concept of law might vary from case to case. ${ }^{88}$ In order to strengthen the authority of the Government, the colonial legislature imposed strict penalties for sedition, the offence of haatzaai. There is little to support the idea that justice was the paramount concern of colonial legal practice.

Despite this, there was, during the last half century of Dutch rule, a group of altruistic scholar-lawyers who developed the material of the indigenous legal cultures in the Indies and created a major academic discipline. ${ }^{89}$ Among other distinctions, they offered the following major contrast between the legal culture of the West and that of Indonesian peoples. The West concentrated on the rights and obligations of the individual person. On the other hand, they said, Indonesians tended to look first at the interests of families, or wider social groups who might be concerned. Then, perhaps, they might consider the rights and wrongs of a particular case. The function of the customary law forum was not so much to realize justice; it was rather more to maintain or to restore social harmony. It is not hard to see how this contrast might be employed in defense of court conduct during the subversion trials.

The influence of this teaching led one of the founders of the nation, the law professor, Supomo, to oppose the inclusion of a human rights section in the Constitution (UUD 45). The national leaders had constructed the Constitution on the basis of the family principle (aliran pikiran kekeluargaan), he said. Supomo argued that explicit mention of individual entitlements would create a document that was intrinsically incoherent. In any case, he argued, the concept of the single person as such is void. The community is more important: it is the community which invests the single person with whatever significance that she/he may have. ${ }^{90}$

He was ably supported by Sukarno, who identified individualism with liberalism (the first step in a chain of associations that led to the evils of colonialism and imperialism). Free speech, free assembly, free voting - of what use was the Constitution, he asked, if it could not fill the empty bellies of the starving ${ }^{91}$

The Provisional Constitution of 1950, the Undang-undang Dasar Sementara, contained the complete text of the UN Universal Declaration of Human Rights. This commitment was lost, however, in 1959 with the reversion to the UUD 45. Its omission may reflect the views, and show the influence, of Supomo and the others. Or they, in turn, may have done no more than express the views then prevailing in the legal culture. Either way, the legal culture which developed from those origins now appears indifferent to the citizen's entitlements. ${ }^{92}$ It has been condemned by various defense counsel and by overseas critics.

${ }_{88}$ Ruth McVey, The Rise of Indonesian Communism (Ithaca, N.Y.: Cornell University Press, 1965) p. 26 or Hooker, Laws, p. 291.

${ }^{89}$ As part of the general reorientation in the Netherlands colonial policy-the Ethische Koers-at the turn of the century (ca 1900), the University of Leiden established and developed a discipline within its law faculty for the study of legal mores and customs (adatrecht) in the Indies.

90 Other lawyers opposed the development of explicit individual rights in the laws of independent Indonesia. See, for instance, the statement cited from the works of M. M. Djojodigocno in Hooker, Adat Law, p. 28.

${ }^{91}$ A. Hamzah, Perlindungan Hak-hak Asasi Manusia dalam Kitab Undang-undang Hukum Acara Pidana (Bandung: Binacipta, 1986), pp. 9-12 or Ali Basja Loebis, Undang2 Dasar RI 1945 (Sedjarah Pertumbuhan dan Pendjelasan Pasal2nja) (Surakarta: Universitas Tjokroaminoto, n.d.).

92 See the case of Sumartono Saat described in 't Hart and Nusantara, Hukum Acara Pidana, p. 77ff. This case has nothing to do with Tanjung Priok or the subversion trials: I chose it for that reason. The behavior of the 
"It is far more important that justice should seem to be done" -that would be a teaching consistent with the myth of Power. Formal law, the proclamation of the authority and the values of the Pancasila state would, under this view, carry greater weight than other details of procedural law. And substantive law would be less substantial than either. It would be consistent with that teaching if courts were to function, not as a counterweight to the executive power but, rather, as a supplementary actor in the ritual vindication of sovereign authority. It has been suggested that the state in Indonesia functions as a theater; 93 that stage management and show are the essential business of government.

The subversion trials could be viewed in the same light. They constituted political drama. The Republic, menaced by alien and awesome power, marshalled its forces. At the denouement, in the theater of the court, the state was vindicated: its enemies were shown to be disconcerted and impotent. The drama may be re-enacted at various times in different locations. The cast may change. But-say the cynics-the plot will remain essentially the same. ${ }^{94}$

\section{Conclusion}

This article has examined the component ideas of four major dynamics of human action in Indonesia-the several beliefs that the state, or Allah, or justice, or power ... is the supreme consideration in social life. But rarely, if ever, is there a perfect match between analytic model and social reality. Different personal motives may account for the same observed behavior. The final question, then, should not be: which of these interpretations gives the truth? Instead, it might be more appropriate to ask: which idea most closely fits the Indonesian situation? So I shall review each myth in turn.

The Pancasila state is the myth of those who see the emergence of the Indonesian nation state as the culmination of a long historical struggle. The process required the emerging polity to free itself first from the shackles of colonial servitude, then from entanglements with other international systems and ideas. The Old Order fiction of Nasakom-that is: of alliance among nationalists, the enthusiasts for religion, and Communists-was repugnant under the Orba, not only because of the history of the New Order's origin, but also because it called in question the self-sufficiency of undiluted Indonesian nationalism. Following this interpretation, it was historically necessary that the Indonesian state should sever ideological relations with erstwhile allies: at once, under the New Order, with international Marxism and socialist materialism; then, equally inevitably, with the spiritual dynamics of the great world missionary religions. In place of these ideologies the governing establishment would install the Pancasila for-

executive officers reported here shows lack of responsibility. Sumartono Saat was allegedly drunk when arrested. Three months later he was still in jail. He had not been charged. No legal process of any sort had been initiated. This, the Country Court of South Jakarta found, was in breach of the law. It awarded damages against the government, as compensation to Sumartono Saat. At the time that the report was written (1986), four years after the illegal detention, the damages were still to be paid. Saat's case warrants the assertion that neglect of KUHAP regulations is not peculiar to the subversion trials.

${ }^{93} \mathrm{Cf}$. Clifford Geertz, Negara, the Theatre State in Nineteenth Century Bali (Princeton, NJ: Princeton University Press, 1980).

${ }^{94}$ Occasional incidents in the conduct of the trials added plausibility to this interpretation. Abdul Rani Yunsih, for instance, presented a toy robot to the prosecutor at the conclusion of his trial. This prompted the press to speak of the process as a sandiwara (a dramatic performance). 
mula as the ultimate unique focus of national loyalties. That outsiders may refer to such a project as "proscriptive," "arbitrary," and "illiberal" would matter little to the adherents of this myth. Civil religion is necessary because the emergent state still lacks the minimal consensus which forms the basis of ordered social life. 95 The social contract is fragile: the advocate of the present Pancasila settlement only has to point to the violence associated with the Tanjung Priok demonstration and the subsequent terrorist attacks on buildings and life to justify (in his eyes) the need to quench enthusiasm for Islam. It was unfortunate that the trouble-makers added to the difficulties of sound government when they challenged the official explanations. That was subversion: a "subversive" is a person who does not value above everything else the hard-won independence and integrity of the status quo nation state. Subversi is rocking the boat. It is the prime and ritual function of the Indonesian judiciary, as it ever was, to restore the equilibrium. So much for the New Order myth of the Pancasila state: it is, in Popper's terms, a closed society reacting to the fear of flux. ${ }^{96}$

To indicate the variety among Islamic doctrines, I have outlined some of the human responses to the assertion that the Creator-God is supreme, that His will is irresistible, and that $\mathrm{He}$ is concerned with every particular of social life. Many Muslims have felt so convinced of this claim that they have committed themselves to the realization of His supremacy in government. Many of them have tried to persuade their fellow-citizens that this is an inescapable obligation and that the task is immediate. Some have been so overwhelmed by their sense of the All-Powerful that they have felt called to demonstrate this quality with flame, noise, death, and destruction. Against this, there are other Muslims who hold that Allah is supremely in charge of the universe He has made and that $\mathrm{He}$ needs no assistance from His creatures. He requires nothing but personal obedience; no organization of a daru'l-Islam. If the social program of Islam is to be achieved by human action, it will be achieved through prayer and persuasion. The Muslim may only take arms against the civil authorities to defend fundamental freedoms of worship, property, life, and liberty. It is hard, though, for a Muslim to decide where the limits lie, between justifiable resistance to oppression on the one hand, and enthusiastic misuse of religion on the other.

It is clear that the Indonesian Muslims would differ among themselves about the meaning of "subversi." Many among the enthusiasts would see it as a badge of honor; a sign worn as a privilege by dissenting preachers like Mawardi Noor and Haji Fatwa, a sign that they spoke the truth in Allah's name, that with no call to rebellion, they commended the good (amar makruf) and condemned (government) wrong (nahi munkar), when they saw it. Many Muslims would withhold the title "subversive" from the bombconspirators, seeing no more in their actions than the banality of crime. Subversi for a Muslim may signify anything from stoic heroism to violent insurrection.

Some prisoners, however, were arrested for reasons not specifically related to Islamic activities or associations. Two of them, Dharsono and Sanusi, incurred official displeasure through their endorsement of the Lembaran Putih call for an enquiry. The advocate, Buyung Nasution, also pursued justice when he could have compromised for the

\footnotetext{
${ }^{95} \mathrm{Cf}$. Clifford Geertz: "... a struggle to create an institutional structure for the country that enough of its citizens would find sufficiently congenial to allow it to function" ("Afterword" in Culture and Politics, ed. Holt et al., p. 322).

${ }^{96} \mathrm{~K}$. R. Popper, The Open Society and Its Enemies (London: Routledge and Kegan Paul, 1986) pp. 204-7 and passim.
} 
sake of harmony and order. He too suffered. Men of any faith-or none-might have done as much.

Perhaps, a cautionary tale can be cited, drawn from the myths of religion-not Islam, but the tradition of old Java. Power is manifest in the display of unity at the center of the realm. So, should one of the sages, the kiayi, become estranged from the court establishment, he would withdraw or perhaps he would be exiled to the periphery, the outer mountain margin of the state. Should he survive, his intransigence would witness to a flaw in the heart of the realm. ${ }^{97}$ Dissent itself is a sign, under this interpretation, that the ruler's power has been diminished. Eventually, the dissident kiayi might gather spiritual force-and disciples. He might, in the end, come to constitute the alternative, rival, center for the realm. To what extent does that pattern lend itself to the contemporary scene? This might make sense of Orba's fierce reaction to non-conformists.

The myth of justice teaches that it is not used as a means to any end. But the Javanese tale tells that those who persevere in truth for its own sake sometimes acquire authority as an unplanned by-product. That may be a comforting myth for the virtuous but it presents the power-seeker with a bind. Those who regard power as the ultimate reality of social life cannot acquire it that way.

For this essay, the final exercise is to look at seven men-namely: Hasan Kiat, Haji Fatwa, Muhamad Djabir bin Abubakar, General Dharsono, Sergeant Hermanu, Samin, and Mohamad Nasir-and to reflect on the motives which led each to act at Tanjung Priok or in the trials thereafter. The reader is invited to consider how the major myths might explain their behavior. Kiat presents no problem: he is an avowed Muslim who denies the validity of both the Pancasila and the state founded on those principles. His motivation is loyalty to Allah and the ideal of dar al-Islam. Haji Fatwa's motivation seems more complex: although he is a devout Muslim, he was quite prepared to accept the institutions of the Republic and to work within it. He associated with non-Muslims in Petisi 50 actions. Does the myth of Allah mean any less to him than it does to Hasan Kiat: or does he understand it in a different way? Which of the two ideas-eternal justice or God-sustained Muhamad Djabir through his ordeal: or is it impossible in his case to make such a distinction? Did those ideas sway General Dharsono when he signed the White Paper: were they present in the same degree as they were for the martyred prisoner? Did they support Dharsono through his trial? Or, does it make more sense to regard Dharsono as a loser in the game of power? The reader must decide if that is plausible. Will the myth of power account for the actions of Hermanu? Or is it better to look on him as an unthinking instrument of the national state? If that interpretation will suffice for him, will it also serve for his companion, Samin? He was the Babinsa who obeyed Hermanu's orders at the prayer-house; he was said to have expressed disquiet about his actions. And what ideas inspired Mohamad Nasir, the inflammatory preacher who vanished? Was it zeal for God or was it ambition to replace the governors? This is enough to show how the analysis might be applied: the exercise could be continued; similar questions can be asked about anyone connected with the happenings at Tanjung Priok.

${ }^{97}$ See Benedict R. O'G. Anderson, "The Idea of Power in Javanese Culture," in Culture and Politics, ed. Holt et al., especially p. 22. 